\title{
Mat for skogens menn
}

Det var magre kår for skogsarbeiderne i de harde trettiåra - og forpleiningen var dårlig. Anleggene var for små til at man kunne ansette kokke. «Forutsetningene for å innføre felleshusholdning i koiene over Østlandet for tiden ikke er til stede. Driftssesongen er for kort og belegget i koiene for lite. Dette kommer av arbeidsløsheten. Skogsarbeidet blir opdelt i mange små akkorder for å skaffe flest mulig arbeide ialfall en liten tid.» En forstkandidat fikk med hjelp fra professor Carl Schiøtz og hans medhjelpere H. Natvig og husholdningslærerinne frøken Rønnaug Gløersen utarbeidet en proviantliste, som ble lagt til grunn for en kostundersøkelse, publisert i Tidsskriftet nr. 3/1936. «Til kostlisten blev utarbeidet en meny for 1 uke og tilhørende opskrifter som blev utarbeidet av min hustru, Sigrid Wollebæk Andersen.» Forsøket var vellykket - arbeidsprestasjonene var gode, selv om den varierte kosten ikke inneholdt mange kalorier. Noe kunne kanskje tilskrives at kaffeforbruket gikk ned til fordel for kakao kokt på melk (Tidsskr Nor Lægeforen 1936; 56: 139-48).

\section{Kostkontroll med tømmerhuggere 1935.}

\author{
Av forstkandidat Sønnik Andersen, Mesnali.
}

Fylkeslæge Andersen foreslo i vår (1935) i et møte av skolestyreformenn for Opland fylke på Lillehammer at guttene $i$ skogsbygdene skulde få adgang til å delta $i$ kursene $i$ matstell og husstell. Herved vil man opnå en mere almindelig forståelse av at en riktig kost gir god helbred, og guttene vil, når de senere står overfor det praktiske tilfelle selv å skulde sette sammen kostlisten og å lage til maten, ikke være helt fremmede for hvad de har å gjøre.

Våren 1935 fikk jeg av Statssekretær Aall og hustrus legat kr. 500 til fortsatte undersøkelser av skogsarbeidernes levevilkår. Arbeidsplanen var ganske enkelt å sette op en «standardproviantliste» og få nogen tømmerhuggere til å bruke denne under sitt arbeide. Formålet var herigjennem å søke å forbedre kostholdet i særhusholdningene i skogshyttene. Tømmerhuggerne fikk den instruks at de skulde søke å holde sig efter kostlisten ; men hvis de trengte noget utover hvad listen inneholdt, skulde de ha adgang hertil mot at undersøkeren fikk nøiaktig rede på hvad der blev anskaffet utenom. Tilovers bleven proviant blev veid. Huggerne skulde føre opgave over sine arbeidsprestasjoner for hver dag og deres legemsvekt kontrolleres så ofte som undersøkeren bestemte. Kosten fikk de gratis. (...)

Forandringer i legemsvekt.

Til denne oversikt over arbeidernes legemsvekt skal bemerkes: Arbeiderne 1, 2 og 3 hugget sammenhengende mellem 1ste og 2nen veining. Mellem 2 nen og 3 dje veining blev hugsten innstillet i 5 dager fordi kjøreren ikke rakk å lunne efter. På disse 5 dager + tiden til næste veining har de gått ned i vekt. Arbeider 4 hadde spart på provianten de første dager, da han trodde det ikke var tilstrekkelig, spesielt trodde han det var for lite brød. Efter at han hadde brukt listen nogen dager - og var blitt mere kjent med den — fant han at det var tilstrekkelig allikevel. Nedgangen i vekt trodde han kom herav; men det kan like godt være et treningsspørsmål. (...)

Arbeidsprestasjoner. De 4 huggere er øvede huggere og meget dyktige. Arbeidsprestasjonene må derfor nærmest ansees å være maksimalydelser. 3 huggere hugget i lag, disse har i undersøkelsestiden hugget 41,3 stokker som inneholder $7,3 \mathrm{~m} .{ }^{3}$ pr. mann pr. dag. Den 4de, som hugget alene, har gjennemsnittlig pr. arbeidsdag 42,6 stokker med 8,05 m. ${ }^{3}$ Alt dette er ubarket sagtømmer. Der hvor tømmeret barkes, er dagsprestasjonene langt under dette, da barkingen utgjør en ganske stor del av arbeidet. (...)

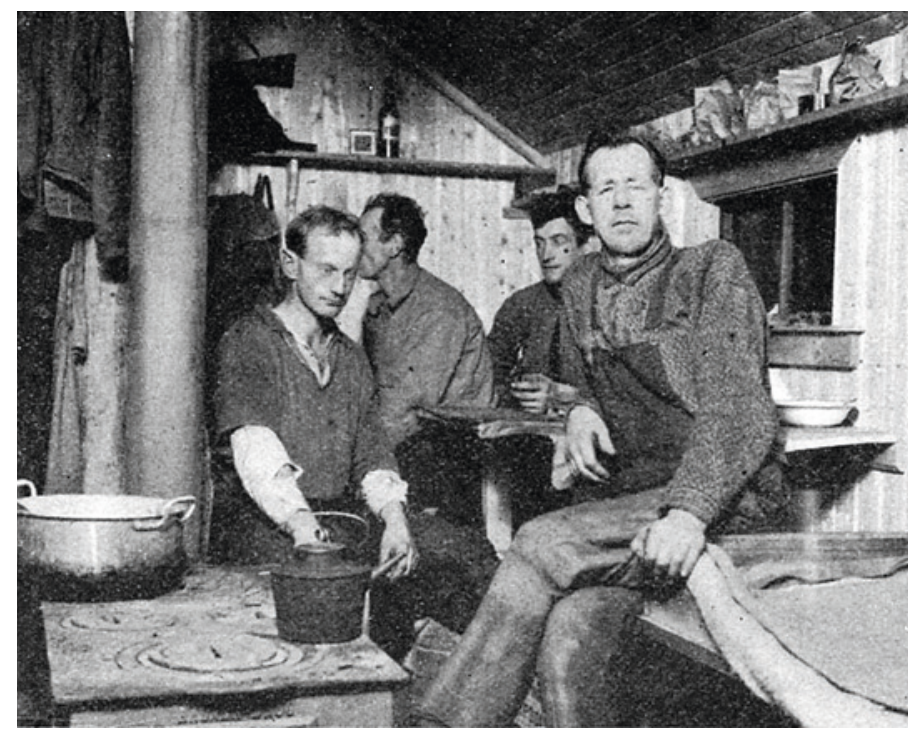

Angående proviantlistene er å merke at de er beregnet på det vanskeligste tilfelle, nemlig at skogsarbeideren intet har å ta med hjemmefra, alt kjøpes hos landhandler. I de tilfelle hvor en del av provianten som middagsmaten, melk, brød, flatbrød, lefse og lignende tas med hjemmefra, vil provianten falle forholdsvis billigere. Den proviant som blev brukt i kostkontrollen, kom på kr. 1,67 pr. kostdag. Det beregnede matøre var 166. Materialet fra kostkontrollen har jeg tenkt å bearbeide videre og av det søke å trekke ut de ting som kan være av effektiv nytte til forbedring av kostforholdene i særhusholdningene i koiene. For at resultatet skal komme tømmerhuggerne til gode, har jeg tenkt at det måtte gå an å utarbeide et lite hefte på ca. 10 sider som skal inneholde: Regler for renhold i skogshytter, proviantlister, menyer, opskrifter og anvisning til førstehjelp ved skader. Blir der plass til det, burde de viktigste ting man har å iaktta under valg av koietomt, tegning og bygging av koien og skogstaller også medtas (jfr. 3). Dette hefte måtte forutsettes ikke å koste mere enn 20 -25 øre og være å få kjøpt hos landhandlere. Muligens kunde det bære sig økonomisk om man tok inn et begrenset antall annonser. 